\title{
Workers' Knowledge and Practice About Occupational Hazards and Safety Measures in Bakeries at Assuit city
}

\author{
Omima M. Abad- Elzaher ${ }^{1}$, Hoda D. Fahmy ${ }^{2}$, Neama M. El-magraby ${ }^{3} \&$ Asmaa K. Hassan $^{4}$. \\ 1. Assistants lectures, Community Health Nursing, Faculty of Nursing, Qena University, Egypt. \\ 2. Prof, Community Health Nursing, Faculty of Nursing, Assuit University, Egypt. \\ 3. Assistants professors, Community Health Nursing, Faculty of Nursing, Assuit University, Egypt. \\ 4. Assistants professors, Community Health Nursing, Faculty of Nursing, Assuit University, Egypt.
}

\begin{abstract}
Back ground: Processing in bakery generates diverse risk on exposed workers. The Aim: assess knowledge, and practices of workers towards occupational hazards and safety measures in bakeries at Assuit city .Design: A descriptive design was utilized. Setting: it was conducted in bakeries at Assuit city .Sample:. A systematic sample was used for selecting the study bakeries. Convenient sample was used (total coverage) for workers in chosen bakeries. Each bakery had average between 7 to 9 workers The total number was 87 workers. Tools: Two tools were utilized; I - Interview Questionnaire Sheet about demographic data, workers' knowledge about occupational hazards, injuries facing the workers. Worker's knowledge about safety measures. II- Observational Checklist was used to assess workers for using safety measures in the bakeries. Results: They clear that $2.3 \%$ of the studied workers mentioned poor lighting consider from physical hazards. It was noticed that $17.3 \%$ of them sit or lie down workers in a cool or shady area consider from first aid for excessive heat. It show that majority of studied workers done personal hygiene. Conclusion: The majority of the bakeries workers had unsatisfactory knowledge and practice about occupational hazard and safety measures in the bakeries. Recommendations: Programs of health education should be organized and directed for workers to increase their awareness about hazards and safety measures.
\end{abstract}

Keywords: Workers, Occupational hazards, Knowledge, Practices \& Safety Measures.

\section{Introduction}

Occupational health is a multidisciplinary activity aimed at: the protection of the health workers and promotion them by preventing accidents and diseases in occupation and by decreasing occupational factors and conditions hazardous to safety and health at work, the development and promotion of healthy and safe work, environments; and the adaptation of work to workers, and workers to their jobs. (WHO, 2011) Occupational hazards occur in all sectors of occupation. This term signifies both long-term and short-term risks associated with the environment workplace. Short term risks may include physical injury, while long-term risks may be increased risk of developing cancer or heart disease. Occupational injuries related workplace is responsible for reduced work capacity, increased temporary and permanent work disability. The high rate and early onset of chronic diseases contribute to the high expenditure of national health care systems. (Hämäläinen, et al., 2012), (WHO, 2012)

Workplace health hazards of bakery workers are chronic obstructive pulmonary diseases like emphysema and bronchial asthma. Injuries from accidents are equally common among bakery workers. These could arise from slips and falls on wet or uneven floor surfaces. (Fishwick et al., 2011)
Health hazards occur among bakery workers such as musculoskeletal disorders like muscle pains and arthritis arise from manual handling and moving of heavy loads for example while loading a vehicle may occur. Some chemicals hazards occurs in bakeries such as bleach used in cleaning bakeries could cause contact dermatitis and could also be hazardous to the eyes and the respiratory system. Exposure to noise can cause irreversible hearing damage. Indeed hearing defect is one of the commonest health problems among bakers. (Steiner et al., 2011)

protection of workers in their employment from risks resulting from factors adverse to health, adaptation of work to man, and each man to the job. Placing and maintenance of the workers in an occupational environment adapted to his physiological and psychological capabilities. Improvement working conditions; social security. Protection of workers where their employment contract is terminated.

\section{(Stell man, 2014)}

Occupational health nursing role covers sickness absence management, rehabilitation, health surveillance, health assessment, health screening, health promotion, research and development, policy, procedure and audit. Occupational health nurses have the potential to influence the health of a community and improve the general health of nation through 
public health initiatives, reducing health inequalities, reducing social exclusion and sickness absence, by protecting and promoting the health of working population. (American Board for Occupational Health Nurses, 2012)

\section{Significant of the study}

In Egypt increases cases of injuries related to work during the year 2010 by $16.5 \%$ to a record 18495 compared to 15878 cases in the year 2009, an increase of 2617 cases. (Central Agency for Public Mobilization and Statistics, 2012).

Major accidents among the work place health hazards of bakery represent $40 \%$ of injuries related to work are due to slips on wet floors or spillage of dough or other wet ingredients. Uneven and obstructed floor surfaces lead to tripping accidents. Also the heat associated with ovens in a bakery can be a hazard; the excessive heat can affect cardiovascular function for example, causing syncope (fainting) and other consequences. (North Lanarkshire Council, 2014) Health hazards of bakery work are a matter of global concern today. Exposures to occupational hazards in bakeries are generally indicating poor safety standards, Careless handling and cause serious injuries and health problems. So the present study conducted.

\section{The Study Aim}

To assess knowledge, and practice of workers towards occupational hazards and safety measures in bakeries at Assuit city.

Research Questions

- What is the level of workers' knowledge about occupational hazards and personal protective measures in bakeries?

- Are the workers in bakeries use the personal protective equipments to avoid occupational hazards?

\section{Subjects \& methods \\ Design}

A descriptive design was utilized

\section{Setting}

It was conducted at (5) bakeries in East city and (5) bakeries in West city at Assuit city.

Sample size

The total number of bakeries at Assuit city about (89bakeries). It's divided into East and West. The sample included (11\%) from total number of bakeries. Convenient sample was used (total coverage) for workers in chosen bakeries. Each bakery had average between 7 to 9 workers. All workers were included in this study. The total number was 87 workers.

\section{Sampling technique}

According to the Assuit Directorate of Supply record, divided bakeries into two geographical sectors East and West city Systematic random sample technique was used for selecting the study bakeries. The first bakery in the study was selected randomly from the record and then every eight one until the end of the sample.

\section{Criteria of chosen sample}

- All bakeries were included in the study affiliated to Assuit city.

- The sample included (11\%) from total number of bakeries choosing randomly.

- This study was conducted at (5) bakeries in East city and (5) bakeries in West city at Assuit city by using systematic random sample.

- Convenient sample was used for workers in chosen bakeries. Each bakery had average between 7 to 9 workers

\section{Tools of the study}

The study included two tools:

The first tool was an interview questionnaire sheet based on relevant literature. This tool was divided into three parts:

Part (1): demographic characteristics such as (age, working system, previous workers training as occupational hazards, using safety measures and first aid)

Part (2): Worker's knowledge about meaning of occupational health, types of occupational hazards, and injuries facing the workers. Worker's knowledge about safety measures of occupational hazards. (Yossif. \& Abd Elaal, 2012) \& (Emmanuel \& Sussan, 2014).

Part (3): Bakery workers' reporting practice about first aid for emergency situations as (excessive heat). (Yossif. \& Abd Elaal, 2012)

The adopted scoring system for knowledge and reported practice as follow:

Scoring system designed for the assessment of knowledge was 7 questions and workers reporting practice was 7 questions, given 1 grade for correct answer and a zero was given for in correct answers and don't know. The score of each item summed-up and then converted into a percent score. (Satisfactory knowledge $50 \%$ and more, Unsatisfactory knowledge $<50 \%$ ). (Khalaf, 2015)

The second tool: observational checklist Using safety measures for bakeries workers as protective devices as apron, gloves, shoes, ear plugs, hand washing before and after working, and using body mechanics. (Yossif. and Abd Elaal, 2012) \& (Emmanuel and Sussan, 2014) 


\section{Methodology \\ I-Administrative phase}

An approval letter was taken from the Dean of Faculty of Nursing, Assiut University and then from the Deputy Minister of Directorate supply to conduct the study. After full explanation about the aim of the study.

\section{II-Pilot Study}

A pilot study was carried out before starting data collection on $(10 \%)$ workers, were excluded from the total number of study sample. The aim of pilot study was to test the clarity of tools, and to estimate the time required to fill the form. According to the result of the pilot study necessary modification was done.

\section{Validity of tools}

It was checked and revised by panel of three experts in the fields of community health nursing who reviewed the instrument for clarity, understanding and applicability.

\section{Reliability test}

Reliability was applied by the researchers for testing the internal of the tool, by administration of the same tools to the same subjects under similar conditions two time 15 days apart. Cronbach's Alpha reliability for knowledge was 0.791 and for practice were 8.43

\section{III- Data collection Phase}

\section{Ethical Consideration}

The study was approved by ethical review committee Faculty of Nursing Assuit University. The workers were recruited to the study informed about the objectives of the study. A verbal consent was obtained from the workers. Confidentiality of obtained information was assured and used only for the purpose of the study.

\section{Field work}

Data were collected during the period from the first of September 2015 until the half of November 2015. It consumed about 2.5 months. The researcher couldn't divide the workers to groups to prevent work interruption. Each bakery worker was interviewed individually by introducing self to the workers then explaining the purpose of the study and obtaining his approval to participate in the study with confidentiality. The average time taken to complete each interview ranged from 20- 30 minutes. Each bakery contain from 7-8 workers collect data from each bakery 2 days per week. Every day meet 4 workers. Each bakery ending in 2 days per week until ending the sample in ten weeks.

Statistical analysis

Statistical analysis was done using software SPSS version 19. . (Frequency, percentage, mean and standard deviation) were calculated, as well as tests of significance. (Mann-Whitney, Kruskal Wallis test). $\mathrm{P}$-value considered statistically significant when less than 0.05 . 


\section{Results}

Table (1): Distribution of bakeries' workers regarding to their Demographic characteristics at Assuit city, 2016. $(\mathrm{N}=87)$.

\begin{tabular}{|c|c|c|}
\hline Variables & No. $(n=87)$ & $\%$ \\
\hline \multicolumn{3}{|l|}{ Age: (years) } \\
\hline$<25$ & 35 & 40.2 \\
\hline $25-30$ & 21 & 24.1 \\
\hline$>30$ & 31 & 35.7 \\
\hline Mean \pm SD (Range) & \multicolumn{2}{|c|}{$29.06 \pm 10.36(15.0-55.0)$} \\
\hline \multicolumn{3}{|l|}{ Educational status: } \\
\hline Illiterate/ read and write & 30 & 34.5 \\
\hline Basic education & 13 & 15.0 \\
\hline Technical secondary & 44 & 50.5 \\
\hline \multicolumn{3}{|l|}{ Marital status } \\
\hline Single & 37 & 42.5 \\
\hline Married & 50 & 57.5 \\
\hline \multicolumn{3}{|l|}{ Working system in the bakery } \\
\hline Working at morning & 34 & 39.1 \\
\hline Working at night & 53 & 60.9 \\
\hline \multicolumn{3}{|l|}{ Years of experience in the bakery } \\
\hline$<5$ years & 40 & 46.0 \\
\hline $5-10$ years & 27 & 31.0 \\
\hline$>10$ years & 20 & 23.0 \\
\hline Mean \pm SD (Range) & \multicolumn{2}{|c|}{$7.56 \pm 7.03(1$ year- 30 yrs $)$} \\
\hline \multicolumn{3}{|l|}{ Attending training courses } \\
\hline Yes & 21 & 24.1 \\
\hline No & 66 & 75.9 \\
\hline \multicolumn{3}{|l|}{ Subjects of training courses } \\
\hline Introduction to work and know the risks that can occur & 11 & 52.4 \\
\hline How to deal in a state of emergency for occupational safety & 10 & 47.6 \\
\hline
\end{tabular}

Table (2): Knowledge about occupational hazards among studied bakeries' workers at Assuit city, 2016. $(\mathrm{N}=87)$

\begin{tabular}{|l|c|c|}
\hline \multicolumn{1}{|c|}{ Variables } & No. $(\mathbf{n}=\mathbf{8 7})$ & \% \\
\hline Definition of occupational health & \multicolumn{2}{|c|}{} \\
\hline Correct & 9 & 10.3 \\
\hline Incorrect & 78 & 89.7 \\
\hline Physical hazards: $\neq$ & \multicolumn{2}{|c|}{} \\
\hline Heat and cold & 78 & 89.7 \\
\hline Poor lighting & 2 & 2.3 \\
\hline Noise & 23 & 26.4 \\
\hline Biological hazards: & \multicolumn{2}{|c|}{} \\
\hline Viruses & 6 & 6.9 \\
\hline Bacteria & 1 & 1.1 \\
\hline Viruses and bacteria & 0 & 0.0 \\
\hline Don't know & 80 & 92.0 \\
\hline Chemical hazards: & \multicolumn{2}{|c|}{} \\
\hline Gases & 0 & 0.0 \\
\hline Chemical liquids & 23 & 26.4 \\
\hline Don't know & 64 & 73.6 \\
\hline
\end{tabular}




\begin{tabular}{|l|c|c|}
\hline \multicolumn{1}{|c|}{ Variables } & No. $(\mathbf{n = 8 7})$ & \% \\
\hline Psychological hazards: $\neq$ & \multicolumn{2}{|c|}{} \\
\hline Stress & 39 & 44.8 \\
\hline Fear & 14 & 16.1 \\
\hline Insecurity & 31 & 35.6 \\
\hline None & 25 & 28.7 \\
\hline
\end{tabular}

$\neq$ There is more than one answer

Table (3): Distribution of bakeries' workers regarding to their reporting practice of first aid for excessive heat at Assuit city, 2016. ( $\mathrm{N}=87)$.

\begin{tabular}{|l|c|c|}
\hline \multicolumn{1}{|c|}{ First aid for excessive heat $\neq$} & No. $(\mathbf{n}=\mathbf{8 7})$ & \% \\
\hline Sit or lie worker down in a cool, shady area & 15 & 17.3 \\
\hline Drink plenty of water & 70 & 80.5 \\
\hline Cold compresses with/ice packs & 64 & 73.6 \\
\hline Spraying cold water on all parts of the body & 30 & 34.5 \\
\hline Place wet blankets & 10 & 11.5 \\
\hline Eat a lot of fruit, fresh vegetables & 22 & 25.0 \\
\hline Stand not in the sun under any circumstances & 70 & 80.5 \\
\hline
\end{tabular}

$\neq$ There is more than one answer

Table (4): Distribution of bakeries' workers regarding to their Observational for using safety measures at Assuit city, 2016. (N=87).

\begin{tabular}{|c|c|c|c|c|}
\hline \multirow{2}{*}{ Variables } & \multicolumn{2}{|c|}{ Done } & \multicolumn{2}{|c|}{ Not Done } \\
\hline & $\begin{array}{l}\text { No. }(n= \\
87)\end{array}$ & $\%$ & No. $(n=87)$ & $\%$ \\
\hline $\begin{array}{l}\text { Personal protective equipment } \\
-\quad \text { Wear Apron }\end{array}$ & 0 & 0.0 & 87 & 100.0 \\
\hline - $\quad$ Wear Gloves & 3 & 3.4 & 84 & 96.6 \\
\hline - $\quad$ Wear Shoes/ boots & 83 & 95.4 & 4 & 4.6 \\
\hline - $\quad$ Wear Facemask & 0 & 0.0 & 87 & 100.0 \\
\hline - Wear Hat & 2 & 2.3 & 85 & 97.7 \\
\hline - Wear Ear plugs & 1 & 1.1 & 86 & 98.9 \\
\hline $\begin{array}{l}\text { Personal hygiene } \\
\text {-Hand washing before and after beginning work } \\
\text {-Cleanliness of face, hair and nails }\end{array}$ & $\begin{array}{l}76 \\
79\end{array}$ & $\begin{array}{l}87.4 \\
90.8\end{array}$ & $\begin{array}{c}11 \\
8\end{array}$ & $\begin{array}{c}12.6 \\
9.2\end{array}$ \\
\hline Using handkerchief & 19 & 21.8 & 68 & 78.2 \\
\hline Using body mechanics & 5 & 5.7 & 82 & 94.3 \\
\hline
\end{tabular}

Table (5): Relationship between demographic characteristics of the bakeries' workers and total score of knowledge about occupational hazards and safety measures at Assuit city, 2016. ( $N=87$ ).

\begin{tabular}{|l|c|c|}
\hline \multicolumn{1}{|c|}{ Variables } & Score of knowledge & \multirow{2}{*}{ P-value } \\
\cline { 2 - 2 } & Mean \pm SD & \multirow{2}{*}{0.170} \\
\hline Age: years) & & \\
\hline$<25$ years & $23.46 \pm 3.50$ & \multirow{2}{*}{$0.001^{*}$} \\
\hline 25 - 30 years & $23.52 \pm 2.73$ & \\
\hline$>$ 30 years & $22.10 \pm 3.28$ & \\
\hline Educational status & & \\
\hline Illiterate / read and write & $20.90 \pm 3.85$ & \\
\hline Basic education & $22.62 \pm 2.84$ & \\
\hline Technical secondary & $24.52 \pm 1.95$ & \\
\hline
\end{tabular}




\begin{tabular}{|l|c|c|}
\hline \multicolumn{1}{|c|}{ Variables } & Score of knowledge & \multirow{2}{*}{ P-value } \\
\cline { 2 - 2 } & Mean \pm SD & \multirow{2}{*}{0.415} \\
\hline Marital status & & \multirow{2}{*}{0.661} \\
\hline Single & $23.32 \pm 3.58$ & \\
\hline Married & $22.74 \pm 3.06$ & \multirow{2}{*}{0.327} \\
\hline Working system in the bakery & $22.79 \pm 4.04$ & \\
\hline Morning & $23.11 \pm 2.73$ & \\
\hline Night & & \\
\hline Years of experience in the bakery & $23.45 \pm 3.47$ & \\
\hline < 5 years & $22.96 \pm 3.08$ & \\
\hline 5 - 10 years & $22.10 \pm 3.13$ & \\
\hline$>10$ years & & \\
\hline
\end{tabular}

* Means there is statistical significant difference

Table (6): The relation between total score of practice for using safety measures and demographic characteristics of the studied bakeries' workers at Assuit city, 2016. $(\mathrm{N}=87)$.

\begin{tabular}{|c|c|c|}
\hline \multirow{2}{*}{ Variables } & Score of Practice & \multirow{2}{*}{ P-value } \\
\hline & Mean \pm SD & \\
\hline \multicolumn{2}{|l|}{ Age: (years) } & \multirow{4}{*}{0.214} \\
\hline$<25$ years & $3.23 \pm 0.65$ & \\
\hline $25-30$ years & $3.10 \pm 0.54$ & \\
\hline$>30$ years & $2.90 \pm 0.70$ & \\
\hline \multicolumn{2}{|l|}{ Educational status } & \multirow{4}{*}{0.066} \\
\hline Illiterate/read and write & $2.87 \pm 0.78$ & \\
\hline Basic education & $3.15 \pm 0.55$ & \\
\hline Secondary & $3.20 \pm 0.55$ & \\
\hline \multicolumn{2}{|l|}{ Marital status } & \multirow{3}{*}{0.167} \\
\hline Single & $3.22 \pm 0.63$ & \\
\hline Married & $2.98 \pm 0.65$ & \\
\hline \multicolumn{2}{|l|}{ Working system in the bakery } & \multirow{3}{*}{0.916} \\
\hline Morning & $3.06 \pm 0.78$ & \\
\hline Night & $3.09 \pm 0.56$ & \\
\hline \multicolumn{2}{|c|}{ Years of experience in the bakery } & \multirow{4}{*}{0.103} \\
\hline$<5$ years & $3.25 \pm 0.63$ & \\
\hline $5-10$ years & $3.00 \pm 0.55$ & \\
\hline$>10$ years & $2.85 \pm 0.75$ & \\
\hline
\end{tabular}

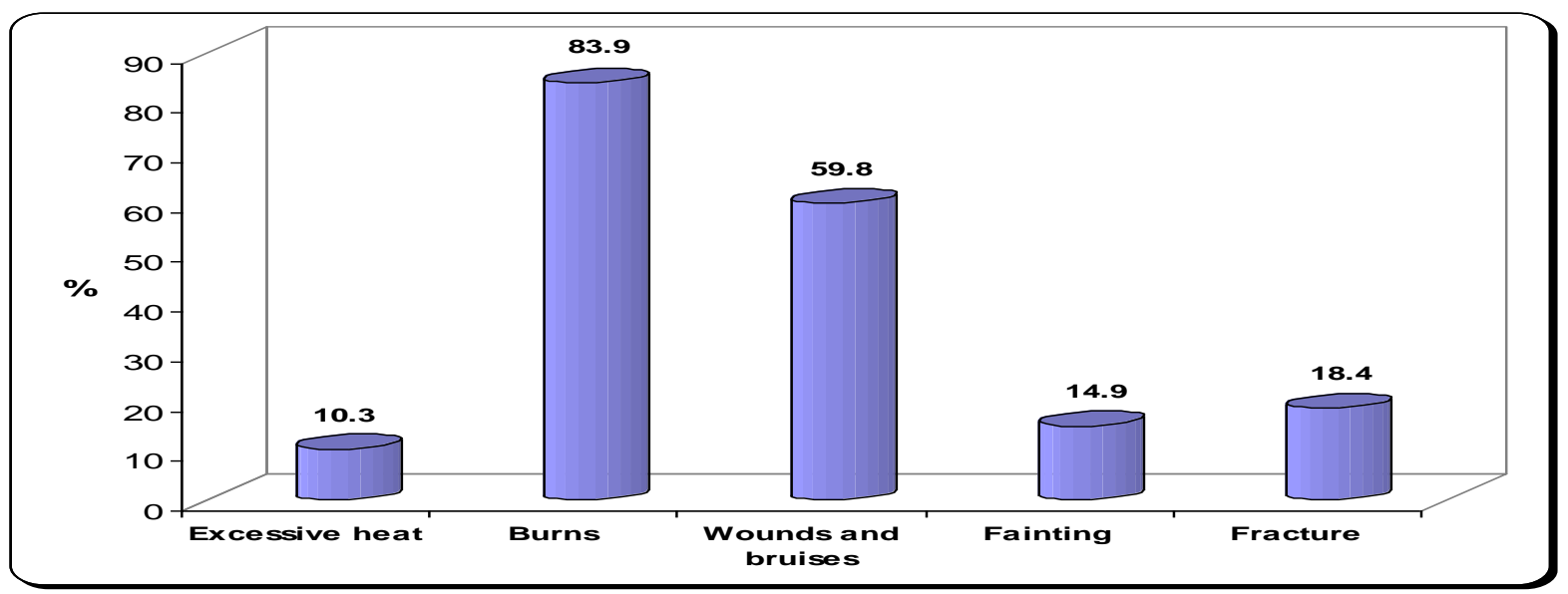

Fig (1): Knowledge of bakeries' workers about injuries at Assuit city, 2016. 


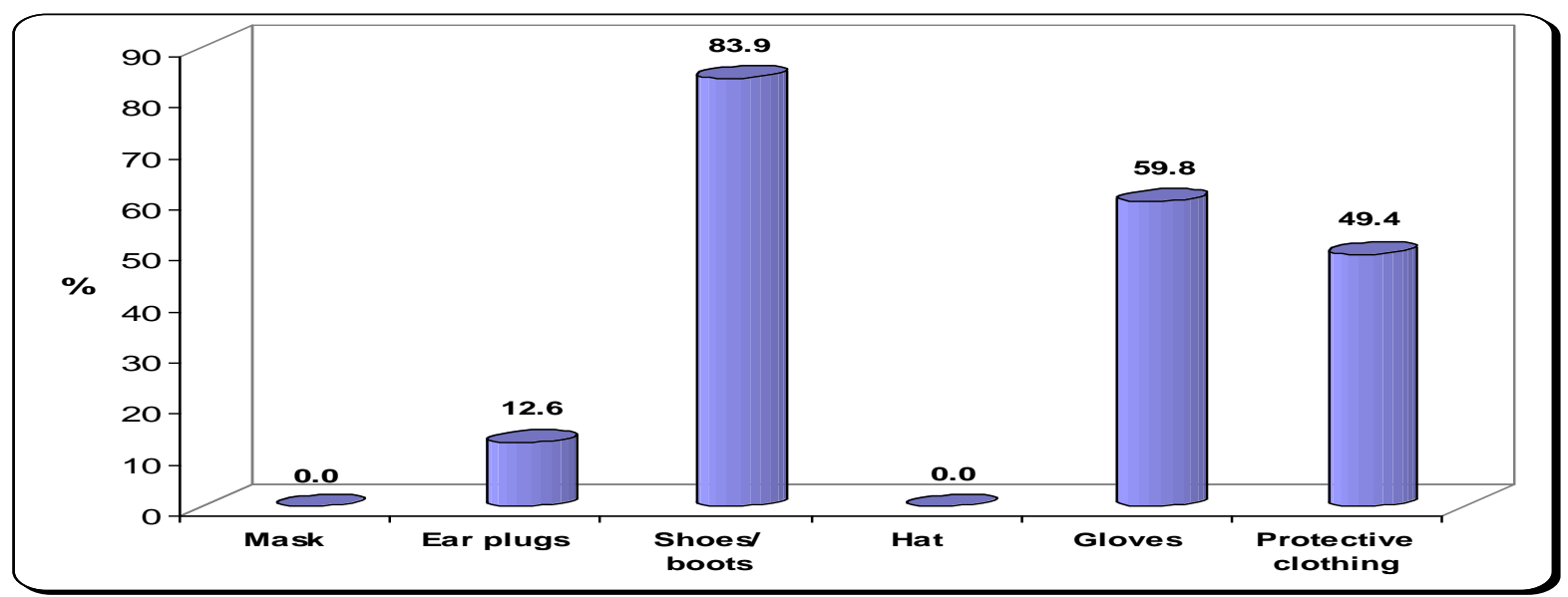

Fig (2): Distribution of studied bakeries' workers regarding to thier knowledge about using personal protective equipment at Assuit city, 2016

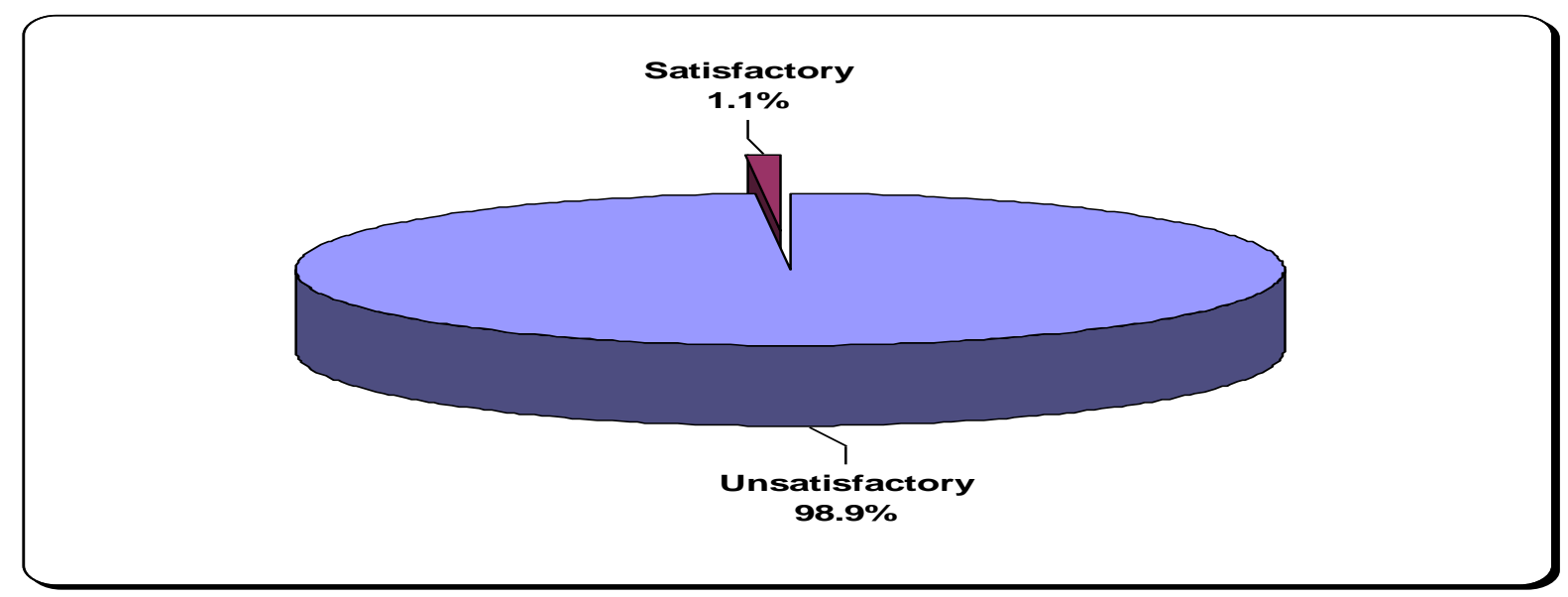

Fig (3): Total knowledge score of bakeries' workers about occupational hazards and safety measures at Assuit city, 2016.

Table (1): Shows demographic characteristics of the studied bakeries workers, it was found that $40.2 \%$ of the studied workers aged $<25$ years. In addition, the table shows that $23.0 \%$ had $\geq 10$ years of experience in the bakery.

Table (2): Clears knowledge of workers about occupational hazards. It was observed that most of studied workers $(89.7 \%)$ do not know meaning of occupational health. As well as $26.4 \%$ of them stated chemical liquids consider from chemical hazards.

Table (3): Reveals the distribution of studied bakeries' workers regarding to their reporting practice of first aid for excessive heat. It was noticed that $80.5 \%$ of workers drink plenty water consider from the first aid for excessive heat. Also the table shows that $11.5 \%$ of them put wet blankets on the workers consider from first aid for excessive heat.

Table (4) Shows the observational checklist for using safety measures of bakeries' workers. The study results show only $(1.1 \%)$ of workers wear ear plugs.
As observed from the table $78.2 \%$ of them not using handkerchief.

Table (5): Clears that there is no statistically significantly differences between demographic characteristics of the studied workers and total score of knowledge about occupational hazards and safety measures except educational status $\mathrm{P}=(0.001 *)$,

Table (6): reveals that there are no statistically significantly differences between all items of demographic characteristics of studied workers and using safety measures.

Figure (1): Reveals that $10.3 \%$ of studied bakeries' workers stated excessive heat consider from these injuries. In addition, this figure shows most (83.9\%) of them know burns consider from these injuries.

Figure (2): Shows that $12.6 \%$ of studied workers know earplugs. Also, this figure reveals that majority $(83.9 \%)$ of them stated shoes / boots from personal protective equipment. 
Figure (3): Clears that vast majority (98.9\%) of studied workers had unsatisfactory knowledge.

\section{Discussion}

Bakeries can be a high risk working environment related to occupational hazards. Historical data suggests that 27,000 workers in the bakeries could potentially be exposed to diseases and injuries in the UK and exposure to flour dust will vary depending on bakery size and apply control preventive measures amongst bakeries. (Federation of Bakers, 2012)

Regarding to workers age, the present study showed that more than one fifth of the workers aged from 2530 years with the range $(15.0-55.0)$ years. related to lack of interest of officials to work, which leads to forced labor in a young age because of high prices of goods and living conditions difficult to meet their needs.

The current study supported by Emmanuel \& Sussan, (2014) who conducted a study in University of Nigeria about Assessment of Baking in a Developing Country: The common Hazards, Health challenges, control measures they reported that the participants age between the rang less than 15 and above 30 years.

The present results in the same line with Baatjies, (2013) who conducted a study in University of Cape Town about the occupational risk factors and interventions for baker's allergy and asthma among bakery workers who found that the studied participants aged from 20 to 50 years.

Concerning educational status of the workers, the present results showed that more than one third of them were illiterate A statistical significant differences were observed between workers knowledge with their education $\mathrm{P}=\left(0.001^{*}\right)$. This table illustrates that mean score of the studied workers had technical secondary educational level was $24.52 \pm 1.95$

On the other hand these results disagreed with Yossif \& Abd Elaal, (2011) who conducted a study in Benha University about prevention of health hazards among workers in the bakery who found that less than one fifth of them were intermediate education.

More over the current study confronted with Emmanuel \& Sussan, (2014) who conducted a study in University of Nigeria they revealed that more than two third of studied workers were graduated from secondary school and only $4.0 \%$ of them were no formal education.

According to experience years in the bakery the current results showed that experience years among workers within the range from 1 year to $30 \mathrm{yrs}$ and there were no a statistical significant difference was observed between years of experience with their knowledge and practice $\mathrm{P}=(0.327,0.103$ respectively). This because when the years of experience were increased the bakeries workers knowledge about occupational hazards and how to control it well be increased.

The current study were similar to Baatjies, (2013) conducted a study in University of Cape Town who found that the participants had years of experience in the bakery with the range from $10 \mathrm{~m}$ to 25 years.

In addition the present results confronted with Emmanuel \& Sussan, (2014) they found that more than two fifth of the workers had worked for 5 years or less while only $2.0 \%$ of the bakers had worked longer than 15 years. The workers had years of experience in the bakery with the range from $5 \mathrm{~m}$ to 15 years.

Regarding to attending training course. The results of the current study showed that slightly more than three quarters of them stated that no training course attending during working in the bakery. Because health and safety responsible not provide training course for bakery workers on how to avoid the risks that occur from work, using self protective devices, and first aid.

The present results are in the same line with Yossif $\boldsymbol{\&}$ Abd Elaal, (2011) who conducted a study in Benha University who found that less than one fifth of them received training courses about safety practice at emergency situations as how to use fire extinguisher. Moreover, the current study disagreed with Cohen $\boldsymbol{\&}$ Colligan, (2014), who conducted a study about Assessing training in health and safety in occupation, Columbia, Parkway Cincinnati. They reported that training is increasing workers knowledge of job hazards, and effecting safe work practices and other positive actions in a wide of work sites. Lack of training is a contributing factor to the hazards.

In addition the present study contracted with Alexopoulos et al., (2009) who carried out study about Subjective risk assessment in the Greek and English bakeries. They found that British bakery provided training for workers about safety and health regulations. Workers' training about occupational safety is seen as critical part of human resources management to perform their work efficiently and help them to make the work environment enjoyable and safe for the workers.

As regard to knowledge about meaning of occupational health, the current study clear that most of workers do not know it. In addition more than one fifth of studied workers stated chemical liquids considers from chemical hazards. Because workers not had enough knowledge about occupational hazards occur in the bakeries and safety measures. So the workers need occupational health program about it. 
The current study showed that reporting practice of worker's was unsatisfactory. Regarding to first aid for excessive heat. It was noticed that less than one fifth of studied workers didn't know sit or lie down workers in a cool or shady consider from first aid for excessive heat. These results related to there are no first aid facilities and no personal protective equipment provided in all bakeries.

The present results contracted with Safety Resource Centre, (2010), study conducted in Washington, which reported that the bakery workers should instructed in how to avoid health hazards by following recommended safe work place.

Concerning observational checklist for safety measures for workers. The current results clear that majority of bakery workers done personal hygiene. The study results show only (1.1\%) of studied workers used ear plugs. Due to the bakery workers not had knowledge about personal protective equipments.

The current study is in the same line with Yossif $\boldsymbol{\&}$ Abd Elaal, (2011) who conducted a study in Benha University who found that all of the studied workers had poor score of practice in all items of protective device; as use of apron, mask, head cap, except personal hygiene as hand washing before and after completion of working and using handkerchief.

These results disagree with Emmanuel \& Sussan, (2014) they conducted a study in University of Nigeria found that most of the participants frequently used apron followed by gloves while ear plugs were least worn. Workers are required to maintain good personal hygiene. Facilities are regularly inspected to ensure that equipment and employee comply with health and sanitation regulations.

Regarding to knowledge of the bakery workers about injuries occurs among bakeries workers. The present study found that most of studied workers know burns, wounds and other injuries. Because the working in the bakery is very hard, heavy and there is not enough time for rest. Due to the studied workers work prolonged duration in the bakery so they exposed to many injuries ranging from mild to severe.

These results agreed with Yossif \& Abd Elaal,

(2011) who found that most of studied workers know many injuries as excessive heat, wound and falling during working in the bakery.

According to knowledge of workers about using personal protective equipment among bakeries the present study revealed that majority of them mentioned that shoes / boots. Due to the workers work prolonged time in the bakery so they wear shoes full times to protect themselves from occupational hazards. It was observed that less than one fifth of studied workers know earplugs. Related to workers don't know personal protective devices that used during the work for protecting them from the hazards.

\section{Conclusion}

The current results could be concluded that

The workers had unsatisfactory knowledge about occupational hazard, and safety measures. As well as the workers had unsatisfactory practice about using safety measures of personal protective equipment.

\section{Recommendations}

Based on the current results, the following recommendations are suggested:

- Programs of health education should be organized and directed for workers to increase their awareness about occupational hazards and safety measures.

- Conduct regular training courses to workers regarding hazards in bakery and using of personal protective measures.

- Further studies should be conducted about occupational hazards and safety measures for bakery workers.

\section{References}

1- Alexopoulos, E., Kavadi, Z., Bakoyannis, G., \& Papantonopoulos, S., (2009): Subjective risk assessment and perception in the Greek and English bakery industries, Journal of Environmental and Public Health, PubMed Articles, Vol. 3, No. (1), pp; 15-30.

2- American Board of Occupational Health Nursing - (ABOHN) (2012): Job analysis survey of occupational health nursing practice. Hinsdale, Illinois pp; 2-20.

3- Baatjies, R., (2013): Study of occupational risk factors and interventions for baker's allergy and asthma among supermarket bakery workers, Submitted in partial fulfillment of the requirement for the doctorate degree, University of Cape Town, pp; 10-12.

4- Central Agency for Public Mobilization and Statistics, (2012): injuries and accidents related to work in Egypt Available at: http://www.masress.com/elwady/4917.

5- Cohen, A., \& Colligan, A., (2014): Assessing occupational safety and health training, National Institute for Occupational Safety and Health, Publications Dissemination, Columbia Parkway Cincinnati. Vol. 3, No. (1), pp; 46-76.

6- Emmanuel, N., \& Sussan, A., (2014): Assessment of Baking industries in a Developing Country: The common Hazards, Health challenges, control measures and Association to Asthma, Department of Community Medicine, 
University of Nigeria .Department of Community Medicine. Available online at: www.isca.me.

7- Federation of Bakers, (FOB), (2012): Guidance on "Dust control and health surveillance in Bakeries, Health Risks Division, Occupational Hygiene Unit, Health and Safety Executive, pp; $1-5$.

8- Fishwick, D., Harris, R., and Robinson, E., (2011): Impact of worker education on respiratory symptoms and sensitization in bakeries, Oxford Journals Occupational Medicine., 61(5), 321- 327.

9- Hämäläinen, P., Takala, J., \& Saarela, K., (2012): "Global estimates of occupational accidents", in Safety Science Journal, Vol. 44, No. (9), pp; 137-156.

10-Kalaf, F., (2015): impact of educational program on knowledge of employees about glaucoma at Assuit University, Submitted in partial fulfillment of the requirement for the doctorate degree in Community Health Nursing Facuity of Nursing, Assuit University. Seven international conference in faculty of nursing Helwan University.

11-North Lanarkshire Council, (2009): Safety in bakeries. Available at: http: //www. northlanarkshire.gov.uk/ index.aspx?articleid $=4293$

12-Safety Resource Center, (2010): Bakery operation safety. Available at: http// www. Baker environmental.com.

13-Stellman, (2014): Encyclopedia of Occupational Health and Safety, International Labor Organization, Geneva, Vol. 3 (1): 16- 62.

14- Steiner M., Dick, D., Scaife, S., Semple, P., Paudyal, R., \& Ayres, A., (2013): High prevalence of skin symptoms among bakery workers Institute of Occupational \& Environmental Medicine, University of Birmingham pp; 12-15.

15-World Health Organization, (WHO), (2011): Occupational health A manual for primary health care workers, Regional Office for the Eastern Mediterranean, Cairo pp;14-15

16-World Health Organization, (WHO), (2012): Good Practice in Occupational Health Services, A Contribution to Workplace health, edition 5 , WHO Regional Office for Europe, Copenhagen Worcester Polytechnic Institute , pp; 4-13.

17-Yossif H., \& Abd Elaal E., (2012): Occupational Hazards: Prevention of Health Problems among Bakery workers in Benha City, Journal of American Science, 8(3), 99-108. 